\title{
粉末吸入製剤開発を指向した動態制御学並びに薬剤科学の統合研究
}

\author{
尾上誠良
}

\section{Strategic Formulation Study on Dry Powder Inhalation System Based on Modulated Molecular Properties and Controlled Pharmacokinetics}

\author{
Satomi Onoue \\ Department of Pharmacokinetics and Pharmacodynamics, School of Pharmaceutical Sciences, \\ University of Shizuoka; 52-1 Yada, Suruga-ku, Shizuoka 422-8526, Japan.
}

(Received June 7, 2012)

\begin{abstract}
Cyclosporine A (CsA) has been widely used as an immunosuppressive agent, and recent outcomes from clinical studies are indicative of the potent therapeutic potential of CsA for chronic asthma and airway inflammation. The clinical use of CsA for airway inflammatory diseases is partly limited because of low oral bioavailability and severe systemic side effects. A number of CsA dosage forms have been proposed to overcome these drawbacks, for example, nebulizer formulation and metered-dose inhaler formulation for inhalation therapy, whereas these liquid formulations sometimes contain organic solvents and other solubilizers, leading to local irritant potency. In this context, our group developed a dry powder inhalation (DPI) system of CsA, employing a polymer-based amorphous solid dispersion (ASD) approach, for inhalation therapy on airway inflammations. There was marked improvement in dissolution behavior of the ASD formulation compared with that of an amorphous CsA. The new DPI system of CsA exhibited high dispersibility and suitable particle distribution for inhalation therapy. In vivo experiments demonstrated that inhaled DPI system of CsA attenuated inflammatory events in experimental asthma/chronic obstructive pulmonary disease (COPD) model rats as evidenced by a decrease of infiltrated granulocytes, and there was no excessive increase in systemic exposure of CsA at a pharmacologically effective dose, possibly leading to reduced systemic side effects. From these findings, combination use of CsA-loaded ASD and DPI systems might be a promising approach for the treatment of airway inflammatory diseases with improved pharmacodynamics and lower systemic exposure.
\end{abstract}

Key words_— solid dispersion; amorphous; dry powder inhaler; cyclosporine A; airway inflammation

\section{1. はじめに}

創薬技術の飛躍的発展に伴い数多くの医薬品候補 化合物が創出される昨今, Lipinski らの報告によれ ば当該化合物の約 $40 \%$ 程度が難水溶性薬物である と推定される. ${ }^{1,2}$ 難水溶性化合物は治療薬候補とし て高いポテンシャルを持つものの，その溶解性の低 さから臨床応用が困難になることがあり，それゆえ 溶解性改善が重要な課題となる，溶解性の改善を目 的として, 塩形成3)や準安定型など適切な原薬選択 や,4,5) 微細化, ${ }^{6,7)}$ microenvironmental pH-modifier, ,8,9) エマルション10)やシクロデキストリン11,12)などの各

The author declares no conflict of interest.

静岡県立大学薬学部薬物動態学分野（４４22-8526 静岡 市駿河区谷田 52-1)

e-mail: onoue@u-shizuoka-ken.ac.jp

本総説は, 平成 23 年度日本薬学会東海支部学術奨励賞

の受賞を記念して記述したものである.
種製剂技術の適用が国内外で試みられている. ${ }^{13-15)}$ 特に中性化合物においては塩の形成が困難であるた めに製剂技術の担う役割が極めて重要であり，近 年，実用的な製剤技術開発が急務の課題となってい る。その一環として，注目を集めている製剤技術に 固体分散体（solid dispersion; SD）があり，Chiou \& Riegelmanによれば固体分散体は,「溶融法, 溶 媒法, 又は溶融一溶媒法により調製された, 固体状 態で不活性な担体又はそのマトリックス中に，1種 又はそれ以上の活性成分が分散したもの」と定義さ れる. 16) その長所としては，粒子径の減少や濡れ性 の向上, さらには含有薬物の非晶質状態の維持など が挙げられ, 固体分散体製剂とすることで物理化学

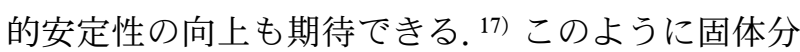
散体製剂は多くの長所を持つことから難水溶性薬物 の溶解性改善技術として有用であると考えられてお 
り，現在では基礎研究に留まらず，応用研究開発の 成果としてイトラコナゾールやニモジピンを始めと して多くの薬物が固体分散体製剤として上市されて いる. ${ }^{13,18)}$

本稿では，難水溶性医薬品である cyclosporine A （CsA）を例として，複数のグループが取り組んで いるCsA の新規製片設計について記述するととも に，筆者らが検討している固体分散体製剂の粉末吸 入製剂への応用についても併せて紹介する.

\section{2. 難水溶性ペプチド CsA の非晶質固体分散体 製剂}

真菌（Tolypocladium inflatum Gams）の培養液 中から単離・同定された CsA は Biopharmaceutics Classification System（BCS）class 2 に分類される難 水溶性ペプチドである. ${ }^{19-21)}$ CsA は強力なカルシニ ユーリン阻害薬であり, 臨床現場においては主に臓 器移植後における拒絶反応の抑制，尋常性乾痒の治 療薬として広く使用されている. ${ }^{22)} \mathrm{CsA}$ はその低い 溶解性に起因して，経口吸収性が低く，かつ患者間

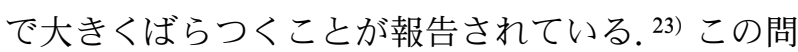
題を解決するため CsA は自己乳化型製剤として開 発されており，最初はマイクロエマルションを形成 するカプセル剂（Sandimmune, Novartis）として 上市されたが，その後，より患者間での吸収性や薬 効の差異減少を目指してナノエマルションを形成す る自己乳化型製剤（Neoral, Novartis）が販売され た. ${ }^{22)}$ 自己乳化型製剤のみならず，基礎研究開発に おいては経口固形製剤の開発も盛んに行われてお り，例えば Tam らは非晶質 CsA のナノ粒子製剤を 開発し, ${ }^{24)}$ Italia らは生分解性ポリマーである PLGA を用いて nanosphere を開発している. ${ }^{25)}$ 他 の高分子を用いた製剤開発も進められており, Choi らはヒアルロン酸を用いて microsphere を試 作し, ${ }^{26)}$ Ubrich らは同様に Eudragit RS/RL を用い

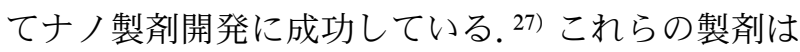
いずれも経口吸収性の著しい改善に成功しており, その臨床応用性についても高く期待されるところで あるが，含有するCsA の安定性についてはかなら ずしも十分な検討や考慮がされていない。そこで筆 者らは CsA の長期保存における物理化学的安定性 をある程度保持させ，なおかつ水への溶解性向上を 同時に達成することを目的として，非晶質状態の CsA を水溶性ポリマーに分散させた固体分散体を

新規に考案した. ${ }^{28)}$

\section{Wet-mill 法による CsA の非晶質固体分散体 製剂調製}

筆者らが検討した固体分散体調製においてはジル コニアビーズと自転公転型攪找機を用いて CsA 原 末の Wet-mill 処理を実施している. ${ }^{28,29)}$ すなわち,

Wet-mill にて粉砕した CsA をポリマー溶液中に分 散させ，回収した懸濁液を凍結乾燥することによつ て CsA 固体分散体製剂を得た。粉末 X 線回折によ つて製剤中に分散しているCsA は非晶質として存 在していることを示唆し [Fig. 1(A)]，本製剂にお ける CsA の非晶質状態は熱分析並びに偏光顕微鏡 観察においても同様に確認できた。本検討において 得た各種 CsA 固体分散体製剂はいずれも顕著な溶 解性の改善を示し, その溶解性改善は使用するポリ マーの種類によって大きく異なる傾向を認めた [Fig. 1 (B) ]. 特に hydroxypropyl cellulose (HPC) を用いた固体分散体製剂において顕著な溶出改善を 認め，また， HPC や polyvinylpyrrolidone（PVP） 等を用いて調製した各種固体分散体製剂の結果を考 慮すれば，同種のポリマー間においては分子量や粘 度が薬物放出特性を制御する因子となっていること を示唆した．比較的分子量の小さい HPC-SSL を用 いた固体分散体製剂の水における初期溶出速度は結 晶 CsA と比して約 150 倍にも及んだが，高分子量 の HPC-L を用いた場合にはその溶出速度は約 22 倍の改善に留まった. 一方, 分子量 $360 \mathrm{kDa}$ のPVP を用いた際には極めて限定的な溶解性改善に留ま り，その初期溶出速度は結晶 CsA のそれと比べて 約 3 倍であった。一般に薬物の溶解は固体表面で起 こる不均一反応であり溶質が界面から内部溶液中へ と移動する拡散過程が律速となることが多いが,

Stokes-Einstein 式によれば薬物分子の拡散係数は粘 度に反比例しており, 今回の知見とよい対応を示し ている。 また，非晶質 CsA，CsA 固体分散体製剂 （それぞれ $10 \mathrm{mg} \mathrm{CsA} / \mathrm{kg}$ ）をラットに経口投与し

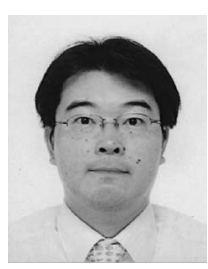

尾上誠良
1998 年岡山大学大学院薬学研究科卒. 2007 年にファイザーより静岡県立大学 薬学部薬物動態学分野講師に就任. 2010 年より現職（准教授）。2011 年日 本薬学会東海支部学術奨励賞受賞. 2012 年日本薬剂学会奨励賞受賞並びに 日本ペプチド学会奨励賞受賞. 研究 テーマ: 薬剤科学. 
(A)
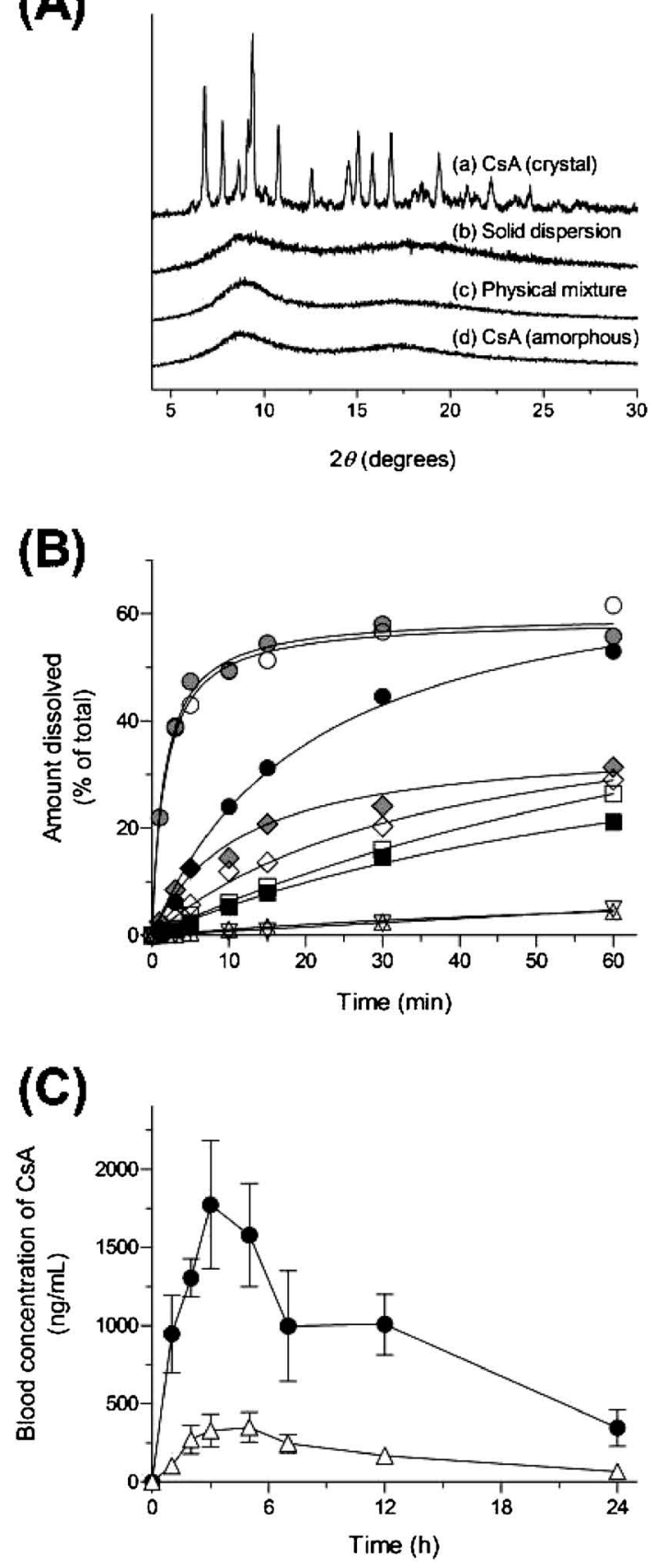

Fig. 1. Physicochemical Characterization of CsA-loaded Solid Dispersions

(A) Powder X-ray diffraction patterns of cyclosporine samples. (B) Dissolution profiles of CsA-loaded solid dispersions in acidic solution ( $\mathrm{pH}$ 1.2) . $\nabla$, Amorphous CsA; $\triangle$, solid dispersion of amorphous CsA with pullulan; O, HPC (SSL); O, HPC (L);, HPC (H); $\square$, polyvinylpyrrolidone (PVP: K30); $\mathbf{\square}$, PVP (K90); $\diamond$, methylcellulose; and $\diamond$, hydroxypropyl methylcellulose (HPMC). (C) Blood CsA concentrations in rats after oral administration of CsA formulations. $\triangle$, Amorphous CsA (p.o., 10 $\mathrm{mg} \mathrm{CsA} / \mathrm{kg}$ ); and 0 , solid dispersion of amorphous CsA with HPC (SSL) (p.o., $10 \mathrm{mg} \mathrm{CsA} / \mathrm{kg}$ ). Data represent mean \pm S.E. of 6 experiments.

た際，その生物学的利用率において固体分散体製剤 は非晶質 CsA と比して約 26 倍の向上を示した [Fig. 1(C) ]. CsA は BCS class 2 に属する薬物で
あるので生物学的利用能は溶解律速と考えられ，す なわち本剤における経口吸収性の顕著な改善は CsA 溶解性の上昇に起因するものと考える.

4. CsA 固体分散体製剤の粉末吸入製剤への応用 近年, CsA は喘息モデル動物において，好酸球 の成熟・分化の抑制作用，気道組織における好酸球 浸潤抑制作用等の興味ある薬理活性を認めてい る. ${ }^{30,31)}$ ステロイド依存性の慢性喘息患者における 米国での臨床試験でもその有用性が報告されてお り，それゆえ，CsAの炎症性呼吸器疾患治療薬と しての臨床応用が強く期待されている。これら興味 ある薬理活性にもかかわらず，高用量の CsA 経口 投与は腎毒性や肝毒性を始めとする全身性の副作用 を惹起する。 この観点から，経口投与以外の投与 ルートの開発が必須であり, 特に炎症性呼吸器疾患 においては吸入療法が適切と考えられているが,

CsA は非常に溶解性が低いために製剂設計が困難 であり，また溶解性向上目的で加えられた添加剤に よる副作用発現も臨床報告されている。 そこで，先 に筆者らが開発した CsA 固体分散体をベースにし て新しい粉末吸入製剂を設計した。本固体分散体製 剂を吸入剂へと応用するため, Jet-mill を用いて吸 入製剂に適した空気力学的粒径に粉砕し，吸入用ラ クトースキャリアーと混合して粉末吸入製剤を調製 した [Fig. 2(A)]。 カスケードインパクターを用い て in vitro 吸入特性を精査したところ，本吸入製剂 は fine particle fraction が約 54\%，カプセルからの 放出量が約 $96 \%$ でありその高い分散性と吸入特性 を確認した [Fig. 2(B)］．抗原感作喘息モデルを用 いて気道における炎症性細胞浸潤を評価したとこ ろ，新規粉末吸入製剂（100 $\mu \mathrm{g}-\mathrm{CsA} / \mathrm{rat} ）$ の気道内 投与によって顕著な浸潤抑制を示し，その効果は物 理混合物（100 $\mu \mathrm{g}-\mathrm{CsA} / \mathrm{rat})$ を気道内投与した際よ りも強いことを確認した [Fig. 2(C)]．また，本結 果は血中あるいは気管支肺胞洗浄液中の各種バイオ マーカー (Myeloperoxidase, Eosinophil peroxidase, Lactate dehydrogenase) のデータと矛盾せず，すな わち，固体分散体製剂技術による CsA の溶解性改 善によって，肺局所における薬理作用が向上したと 考える。CsA 固体分散体製剂の粉末吸入製剂への 発展的応用は呼吸器系局所における高い薬効と薬物 全身暴露量低下を望めることから，安全かつ有効な 喘息治療に寄与するものと期待する. 
(A)

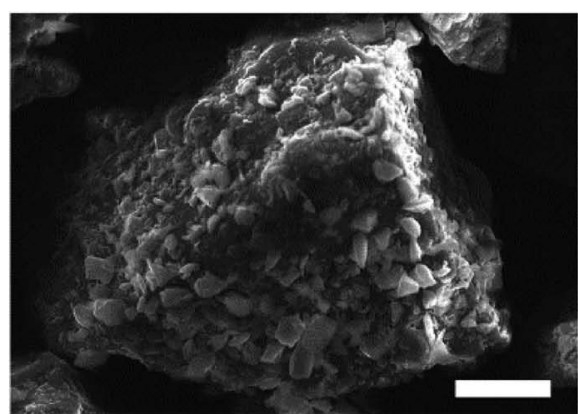

(B)

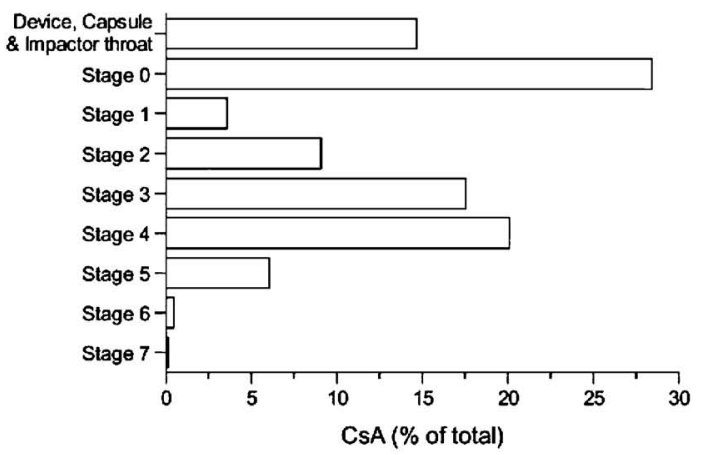

(C)

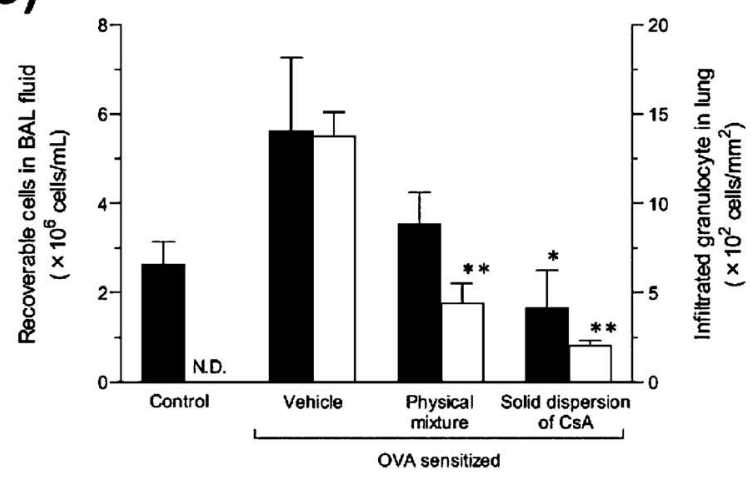

Fig. 2. Inhalable Powder Formulation of CsA

(A) Scanning electroscopic image from inhalable powder formulation. Bar represents $20 \mu \mathrm{m}$. (B) In vitro inhalation performance as determined by cascade impactor analysis. (C) Inflammatory cells in the bronchoalveolar lavage fluid (BALF, filled column) and lung tissues (open column) from antigen-sensitized rats. Data represent mean \pm S.E. ${ }^{*} p<0.05,{ }^{* *} p<0.01$ with respect to vehicle alone in each group.

\section{CsA 固体分散体製剂の課題とその改良}

Wet-mill 法あるいは溶媒法によってそれぞれ調 製した CsA 固体分散体製剂を対象に安定性試験を 実施したところ， $40^{\circ} \mathrm{C} / 75 \%$ 相対湿度条件下におい て保存した場合にはその保存期間に応じて溶出速度 が徐々に低下する傾向にあった. ${ }^{32)}$ この溶出挙動の 変化については，溶媒法によって調製された one-
(A)

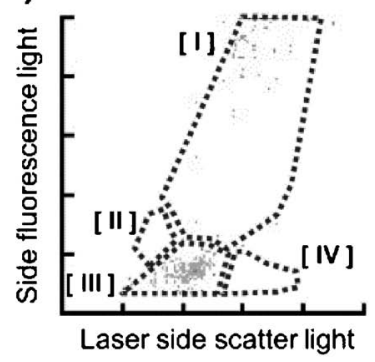

(C)

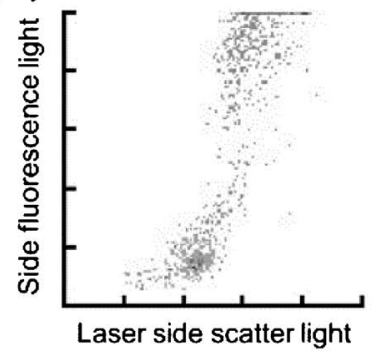

Fig. 3. Cytogram of BALF from Antigen-sensitized Rats (A) Control (non-sensitized); (B) antigen-sensitized rat; and (C) antigen-sensitized rat with pretreatment of inhalable formulation containing CsA dry-emulsions. Cells in BALF were classified as monocytes (I), lymphocytes (II), neutrophils (III), and eosinophils (IV).

phase 型の固体分散体において特に顕著であり, Wet-mill によって得られた two-phase 型の固体分散 体の方が緩やかな溶解性低下に留まった。この安定 性における問題は固体分散体製剂の実用化に向けて の解決すべき課題の 1 つであり, ${ }^{33)}$ より安定した臨 床効果を得るために製剤処方の更なる最適化が望ま れるところである。そこで，今回紹介した固体分散 体製剤に加えて筆者らは最近, CsA を単独の粒子 ではなくドライエマルションとしてポリマー中に分 散させた新規な粉末吸入製剤を開発した. ${ }^{34)}$ 本製剂 は水に接触した後，速やかにポリマーが溶解し，内 封される平均粒子径約 $300 \mathrm{~nm}$ の CsA ドライエマ ルションが均一に分散することが可能であり，溶出 挙動は固体分散体製剂よりも安定している，本製剂 を喘息/chronic obstructive pulmonary disease (COPD) モデルラットに気道内投与した際，同モデル動物に おいて認められた炎症性細胞の著しい浸潤を有意に 抑制することを明らかにし，その効果は特にマクロ ファージと好中球において顕著であった（Fig. 3). 特に好中球性炎症は喘息のみならず COPD におい ても認められる病理所見であり，本製剂が好中球の 浸潤を強く抑制できた事実はたいへん興味深いとこ ろである，今後，各種検討を重ねることで処方の更 
なる最適化を行い, CsA のみならず他の BCS class 2 薬物への応用が期待される.

6. おわりに

既存の医薬品のみならず，現在開発されている候 補化合物においても溶解性の問題はいまだ重要な課 題の 1 つであり, その解決法として適切な原薬形態 の選択や投与形態の開発は今後も必要な検討項目と 考える，特に，現在の医薬品開発においては BCS class 2 に分類される候補化合物が多いとされ，溶 解性を高めることによって安定した臨床効果を得る 試みは極めて重要であろう。その中で固体分散体製 剂技術は既に実用的なものとして認識されている が，より有用性を高めるために，長期安定性の課題 をクリアできる製剤設計・製法や，また，それを容 易に実現する新しいポリマーの開発など技術上の breakthrough が強く期待される.

謝辞当該研究成果は, 静岡県立大学薬学部 名誉教授 故 - 矢内原 昇博士，大阪薬科大学 前理 事長 故 - 矢内原千鶴子博士，静岡県立大学薬学部 山田静雄教授の御指導, 伊藤八ム株式会社医薬品部 門（現 ILS 株式会社）並びにファイザー株式会社 所属時の多くの同僚研究者のご協力，そして当研究 室所属学生の努力の所産であり, 本書面をお借りし て深謝致します。

\section{REFERENCES}

1) Lipinski C. A., Lombardo F., Dominy B. W., Feeney P. J., Adv. Drug Deliv. Rev., 46, 3-26 (2001).

2) Lipinski C. A., J. Pharmacol. Toxicol. Methods, 44, 235-249 (2000).

3) Serajuddin A. T., Adv. Drug Deliv. Rev., 59, 603-616 (2007).

4) Blagden N., de Matas M., Gavan P. T., York P., Adv. Drug Deliv. Rev., 59, 617-630 (2007).

5) Pudipeddi M., Serajuddin A. T., J. Pharm. Sci., 94, 929-939 (2005).

6) Horter D., Dressman J. B., Adv. Drug Deliv. Rev., 46, 75-87 (2001).

7) Mosharraf M., Nyström C., Int. J. Pharm., 122, 35-47 (1995).

8) Onoue S., Inoue R., Taniguchi C., Kawabata Y., Yamashita K., Wada K., Yamauchi Y.,
Yamada S., Int. J. Pharm., 426, 61-66 (2012).

9) Tran P. H., Tran T. T., Lee K. H., Kim D. J., Lee B. J., Expert Opin. Drug Deliv., 7, 647661 (2010).

10) He C. X., He Z. G., Gao J. Q., Expert Opin. Drug Deliv., 7, 445-460 (2010).

11) Loftsson T., Brewster M. E., J. Pharm. Sci., 85, 1017-1025 (1996).

12) Brewster M. E., Loftsson T., Adv. Drug Deliv. Rev., 59, 645-666 (2007).

13) Kawabata Y., Wada K., Nakatani M., Yamada S., Onoue S., Int. J. Pharm., 420, 1-10 (2011).

14) Lobenberg R., Amidon G. L., Eur. J. Pharm. Biopharm., 50, 3-12 (2000).

15) Rajewski R. A., Stella V. J., J. Pharm. Sci., 85, 1142-1169 (1996).

16) Chiou W. L., Riegelman S., J. Pharm. Sci., 60, 1281-1302 (1971).

17) Vasconcelos T., Sarmento B., Costa P., Drug Discov. Today, 12, 1068-1075 (2007).

18) Oshima T., Sonoda R., Ohkuma M., Sunada H., Chem. Pharm. Bull., 55, 1557-1562 (2007).

19) Calderon E., Lockey R. F., Bukantz S. C., Coffey R. G., Ledford D. K., J. Allergy Clin. Immunol., 89, 629-636 (1992).

20) Amidon G. L., Lennernas H., Shah V. P., Crison J. R., Pharm. Res., 12, 413-420 (1995).

21) Wu C. Y., Benet L. Z., Pharm. Res., 22, 1123 (2005).

22) Beauchesne P. R., Chung N. S., Wasan K. M., Drug Dev. Ind. Pharm., 33, 211-220 (2007).

23) Tjia J. F., Webber I. R., Back D. J., Br. J. Clin. Pharmacol., 31, 344-346 (1991).

24) Tam J. M., McConville J. T., Williams R. O. 3rd, Johnston K. P., J. Pharm. Sci., 97, 49154933 (2008).

25) Italia J. L., Bhatt D. K., Bhardwaj V., Tikoo K., Kumar M. N., J. Control. Release, 119, 197-206 (2007).

26) Woo J. S., Piao M. G., Li D. X., Ryu D. S., Choi J. Y., Kim J. A., Kim J. H., Jin S. G., Kim D. D., Lyoo W. S., Yong C. S., Choi H. G., Int. J. Pharm., 345, 134-141 (2007).

27) Ubrich N., Schmidt C., Bodmeier R., Hoffman M., Maincent P., Int. J. Pharm., 
288, 169-175 (2005).

28) Onoue S., Sato H., Kawabata Y., Mizumoto T., Hashimoto N., Yamada S., J. Control. Release, 138, 16-23 (2009).

29) Onoue S., Sato H., Ogawa K., Kawabata Y., Mizumoto T., Yuminoki K., Hashimoto N., Yamada S., Int. J. Pharm., 399, 94-101 (2010).

30) Alexander A. G., Barnes N. C., Kay A. B. Lancet, 339, 324-328 (1992).

31) Nizankowska E., Soja J., Pinis G., Bochenek G., Sladek K., Domagala B., Pajak A.,
Szczeklik A., Eur. Respir. J., 8, 1091-1099 (1995).

32) Sato H., Kawabata Y., Yuminoki K., Hashimoto N., Yamauchi Y., Ogawa K., Mizumoto T., Yamada S., Onoue S., Int. J. Pharm., 426, 302-306 (2012).

33) Ford J. L., Pharm. Acta Helv., 61, 69-88 (1986)

34) Onoue S., Sato H., Ogawa K., Kojo Y., Aoki Y., Kawabata Y., Wada K., Mizumoto T., Yamada S., Eur. J. Pharm. Biopharm., 80, 54 -60 (2012). 